
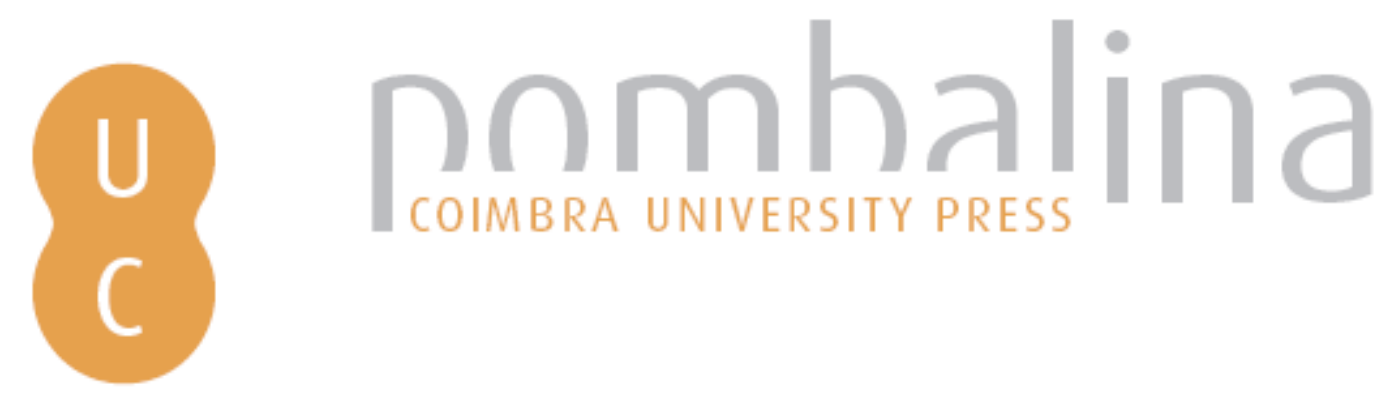

\title{
Development and validation of HPLC-UV method to determine creatinine and metabolites of xylene in urine
}

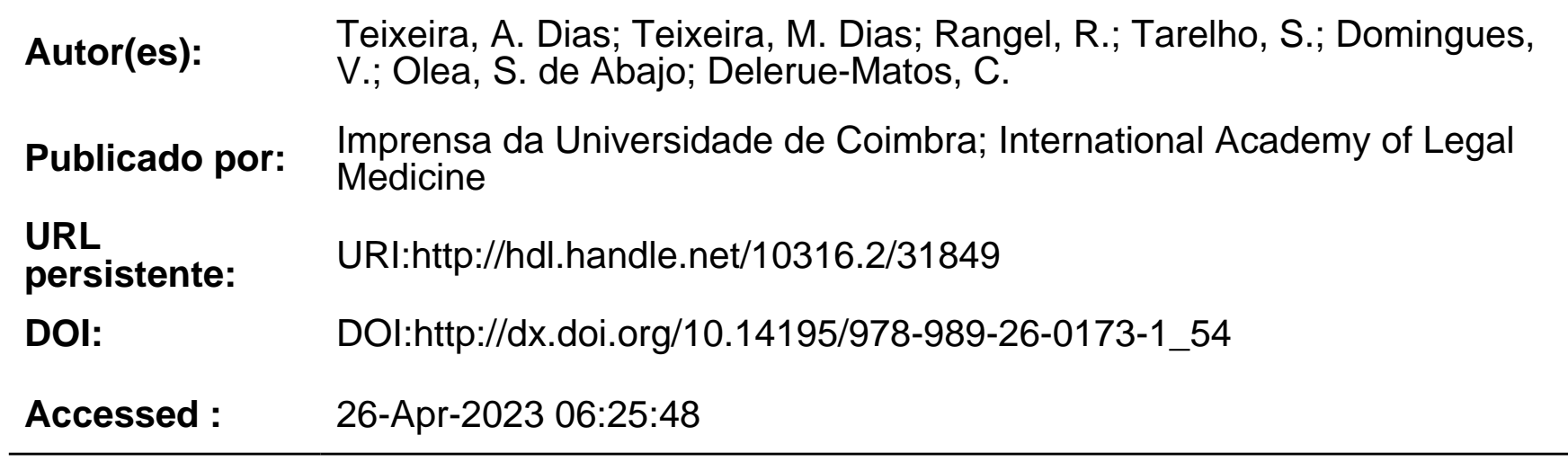

A navegação consulta e descarregamento dos títulos inseridos nas Bibliotecas Digitais UC Digitalis, UC Pombalina e UC Impactum, pressupõem a aceitação plena e sem reservas dos Termos e Condições de Uso destas Bibliotecas Digitais, disponíveis em https://digitalis.uc.pt/pt-pt/termos.

Conforme exposto nos referidos Termos e Condições de Uso, o descarregamento de títulos de acesso restrito requer uma licença válida de autorização devendo o utilizador aceder ao(s) documento(s) a partir de um endereço de IP da instituição detentora da supramencionada licença.

Ao utilizador é apenas permitido o descarregamento para uso pessoal, pelo que o emprego do(s) título(s) descarregado(s) para outro fim, designadamente comercial, carece de autorização do respetivo autor ou editor da obra.

Na medida em que todas as obras da UC Digitalis se encontram protegidas pelo Código do Direito de Autor e Direitos Conexos e demais legislação aplicável, toda a cópia, parcial ou total, deste documento, nos casos em que é legalmente admitida, deverá conter ou fazer-se acompanhar por este aviso.

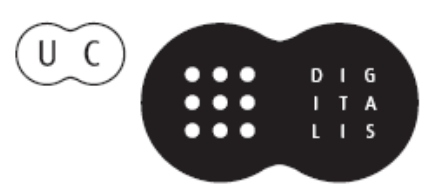




\section{Duarte Nuno Vieira Anthony Busuttil \\ Denis Cusack • Philip Beth}
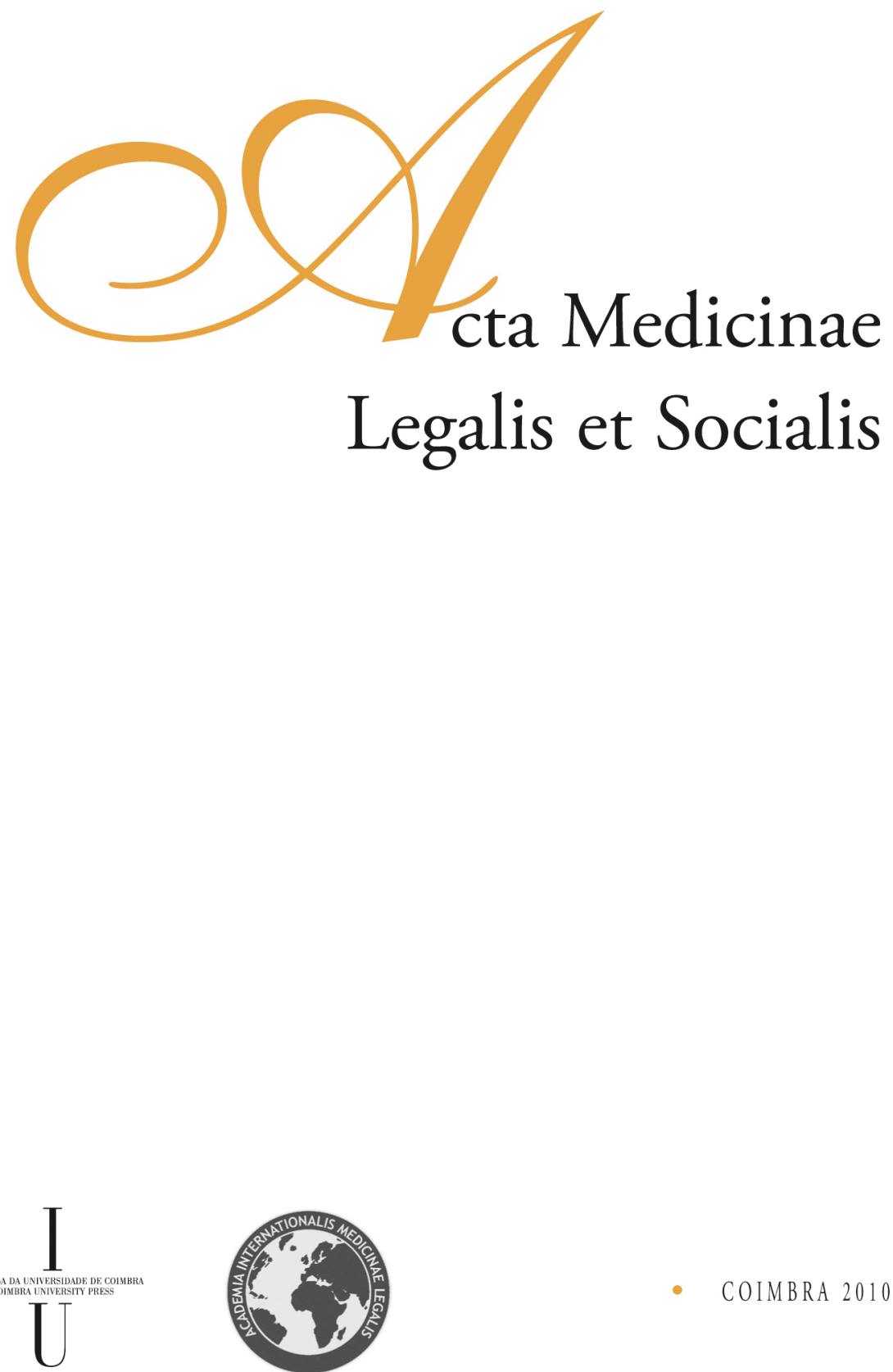
A. Dias Teixeira ${ }^{1}$, M. Dias Teixeira ${ }^{1,3,4}$, R. Rangel ${ }^{4,5}$, S. Tarelho5 , V. Domingues ${ }^{2}$, S. de Abajo Olea ${ }^{3}$, C. Delerue-Matos ${ }^{2}$

1 Engineering Institute of Oporto, Portugal

2 Requimte, Engineering Institute of Oporto, Portugal

3 Biomedical Sciences Department, University of Léon, Spain

4 Health Technologies Research Center, Polytechnic Health Institute of the North, Gandra PRD, Portugal

5 Forensic Toxicology Department, North Branch of the Portuguese National Institute of Legal Medicine, Oporto, Portugal

\section{DEVELOPMENT AND VALIDATION OF HPLC-UV METHOD TO DETERMINE CREATININE AND METABOLITES OF XYLENE IN URINE}

Abstract: A liquid chromatographic (LC) method for simultaneous determination of creatinine and o-, m-, and p-methylhippuric acids (metabolites of xylene) in urine is described. The analytical procedure is based on direct injection in system LC.

With this method, which does not require much time and handling, the different acids can be satisfactorily determined with high sensitivity and specificity. A statistical study shows a good reproducibility for the determination of creatinine, o-, m-, and p-methylhippuric acids. The coefficient of variation for 5 determinations in all cases was less than $2 \%$.

\section{Introduction}

Xylene exists in three isomeric forms (ortho-, meta, and para-xylene). It is a colourless liquid with a typical aromatic odour, volatile and flammable, its vapour is explosive. The commercial product, commonly known as "xylol", is a mixture of all three isomers, with m-xylene predominating (usually 60-70\%). It may contain a small amount ethylbenzene. The xylenes are extensively used as solvents for protective coatings, dyes, inks, and cements; as constituents of aviation gasoline blends and cleaning fluids; and as starting materials and intermediates for chemical synthesis (Ogata, Yamazaki, Sugihara et al., 1980). It's the mayor chemical substance used in Pathological Anatomy Laboratory.

In occupational exposure, xylenes enter the body mainly through the respiratory tract. Pulmonary absorption of vapours is similar for all isomers of xylene and amounts to $60-70 \%$ (Šedivec and Flek, 1976). It remains relatively constant throughout the whole exposure period (Riihimaki, Pfaffli, Savolainen et al., 1979). The percutaneous absorption of xylene vapours is negligible in comparison with the liquid. In humans, xylene is efficiently metabolized. More than $90 \%$ is biotransformed to methylhippuric acid (MHA), which is excreted in urine. Xylene does not accumulate significantly in

\footnotetext{
${ }^{1}$ Corresponding author: Tel.: +351 22 8340500; fax: +351 22 8321159; E-mail address: monica. teixeira@ipsn.cespu.pt.
} 
the human body, and are not normally present in the urine of non-exposed people (Šedivec and Flek, 1976).

Biological monitoring is very important to agreement health to workers. The exposure to organic solvents like xylene, is one of the highest potential risks for millions of persons in workplaces; they can generate substantial environmental pollution leading to outbreaks of public health problems.

The urine methylhippuric acid level has been measured by gas chromatography (Engström J and Bjurström R, 1978; Sz cs, Tóth, Legoza et al., 2002), colorimetry (Ogata M and Hobara T, 1979), thin-layer chromatography (Bieniek, Palys and Wilczok, 1982; Bieniek and Wilczok, 1981) and high performance liquid chromatography (Antunes MV, Patuzzi ALM, Linden R. 2008; Ogata and Taguchi, 1987; Ogata, Yamazaki, Sugihara et al., 1980; Perlingov, Dabrowsk, Stránský et al., 2004).

This study describes a development of a rapid high performance liquid chromatographic with ultraviolet detector (HPLC-UV) method for estimation of metabolites of xylene (o-, m-, pmethylhippuric acid) in human urine. The aim of this work was to validate an appropriate chromatographic method for the simultaneous determination of creatinine and o-, m-, p-methylhippuric acid in urine samples.

\section{Materials and Methods}

\section{Chemicals and reagents}

Analytical standards of creatinine and xylene metabolites (purity 98\%) were obtained from Sigma Aldrich®. Potassium phosphate monobasic anhydrous and orthophosphoric acid were obtained from Merck®. The acetonitrile was obtained from LiChrosolv® (HPLC grade). Ultrahigh purified water was obtained from Milli-Q water dispensing system by Millipore Corporation. HPLC grade solvents and reagents were previously filtered through Teflon filters with porosity of $0.45 \mu \mathrm{m}$ Tracer (TR 200200) and degassed by ultrasound. We used disposable filters Tracer TR 200112, the polypropylene with $0.22 \mu \mathrm{m}$ pore size for filtration of all solutions injected in LC.

\section{Standard solutions and buffer}

Stock solutions of creatinine $(8 \mu \mathrm{g} / \mathrm{mL})$ and each metabolites of xylene $(30 \mu \mathrm{g} /$ $\mathrm{mL}$ ) standard were prepared in ultrahigh purified water and stored at $-4^{\circ} \mathrm{C}$.

The solution of phosphate buffer at $\mathrm{pH} 2.3(50 \mathrm{mM})$ was prepared by dissolving $6.66 \mathrm{~g}$ of potassium phosphate monobasic in $800 \mathrm{~mL}$ of ultrahigh purified water, followed by addition of $4.8 \mathrm{~g}$ of phosphoric acid $85 \%(\mathrm{v} / \mathrm{v})$. The volume was completed to $1000 \mathrm{~mL}$ with purified water and $\mathrm{pH}$ was adjusted with the addition of phosphoric acid or potassium hydroxide, $0.1 \mathrm{M}$.

\section{Instrumentation and analytical conditions}

HPLC analysis was performed on a Varian ${ }^{\circledR}$ liquid chromatography system equipped with a Star 9010 Solvent Delivery System pump, an /visible detector (Star 9050 
Variable Wave length), and a manual injector $(10 \mu \mathrm{L}$ loop) was used. Chromatographic separations were carried out on a Varian ${ }^{\circledR}$ C-18 column (mesh size: $5 \mu \mathrm{m}$; length: 150 $\mathrm{cm}$; internal diameter: $4.6 \mathrm{~mm}$ ). Creatinine and metabolites of xylene were separated by using a linear gradient elution program and the mobile phase was a mixture of phosfate buffer and acetonitrile (Table I). The flow rate was $1.5 \mathrm{~mL} / \mathrm{min}$. The UV detector was fixed at $\lambda=220 \mathrm{~nm}$.

Urine samples, preserved by addition thymol, were collected in polyethylene bottles at the end of the work shift and stored as quickly as possible in a refrigerator at $5^{\circ} \mathrm{C}$. The samples were stable for one week under these conditions, but could be kept for longer if frozen.

\section{Urine samples preparation}

The samples were prepared in glass tubes $(5 \mathrm{~mL})$, only dilution with ultra-purified water (1:10) and centrifugation by $4100 \mathrm{rpm}(5 \mathrm{~min})$. Before the injection, $1000 \mu \mathrm{L}$ of sobrenadant was passed through a $0.45 \mu \mathrm{m}$-pore-size Millipore ${ }^{\circledR}$ filter.

\section{Calibration curves}

The standard calibration curves were obtained by the dilution of reference standard. The dilution was made in ultra-purified water to obtain the concentrations in Table II. Calibration curves were generated from the five calibration samples by analyte peak-area ratio against creatinine, o-mHA and m-, p-MHAs concentration. Linearity was assessed using a weighted least square regression $\left(1 / \mathrm{x}^{2}\right.$ nominal).

\section{Results and Discussion}

\section{Optimization of the method}

A good separation was obtained, with all analytes being resolved and showing adequate peak shapes. Total time of analysis was of $10 \mathrm{~min}$. The retention times were $0.8 \mathrm{~min}$ for creatinine, $7.4 \mathrm{~min}$ for o-MHA and $8.9 \mathrm{~min}$ for $\mathrm{m}-$, $\mathrm{p}$-MHAs. Under our experimental conditions, peaks from other urine components that could interference with the compounds of interest were observed. A typical chromatogram of creatinine, $\mathrm{o}-$ and $\mathrm{m}$-, p-MHAs is shown in Figure I.

\section{Linearity}

The standard calibration curves in the investigated range were linear. The statistical analysis demonstrated that the standar curves in the investigated range were linear from $0.14-100 \mu \mathrm{g} / \mathrm{mL}\left(\mathrm{R}^{2}=0.9991\right) ; 0.14-1750 \mu \mathrm{g} / \mathrm{mL}\left(\mathrm{R}^{2}=0.9979\right)$; and $0.14-1500$ $\mu \mathrm{g} / \mathrm{mL}\left(\mathrm{R}^{2}=0.9876\right)$ for creatinine, o-MHA and $\mathrm{m}-$, $\mathrm{p}$-MHAs, respectively. Table III summarizes the regression data of the calibrations curves, squares of correlation coefficients $\left(\mathrm{R}^{2}\right)$ and maximum squares of correlation coefficients $\left(\mathrm{R}^{2} \mathrm{max}\right)$ of each analyte, for a statistical significance of $95 \%$.

According to the t-test values obtained from t-Student (tobtained) are inferior to the statistical t-test values (tcritical) (tobtained $<$ tcritical), then the adjustment 
of the model is considered satisfactory. The results showed that the squares of the linear correlation coefficients were above 0.99 (Table III), evidencing the linearity occurrence. The regression of standard curves in ultra-purified water was statically significant since the statistical test did not exceed the critical value. The values of $\mathrm{R}^{2}$ and maximum squares of correlation coefficients $\left(\mathrm{R}^{2} \max \right)$ were similar. This indicates that the error due to the analytical procedure, validating the use of the linear model.

\section{Sensitivity}

Creatinine at a concentration of $12.64 \mu \mathrm{g} / \mathrm{mL}$, o-MHA at a concentration 250 $\mu \mathrm{g} / \mathrm{mL}$ and $\mathrm{m}-$, $\mathrm{p}-\mathrm{MHAs}$ at a concentration $250 \mu \mathrm{g} / \mathrm{mL}$ was injected on five different days (inter-assay). The limit of detection (LOD) and limit of quantification (LOQ) of creatinine, o-MHA and m-, p-MHAs in the mobile phase was also determined (Table IV).

The limit of detection was $0.077,0.048$ and $0.048 \mu \mathrm{g} / \mathrm{mL}$, for creatinine, o-MHA and m-, p-MHAs, respectively. The results evidence that the HPLC system and the method are adequate for monitoring creatinine and metabolites of xylene. Precision was expressed as the coefficient of variation $(\mathrm{CV}, \%)$. Values of inter-assay precision were described in Table V. Values below 5\% demonstrate the precision of the method.

\section{Conclusion}

A highly selective HPLC assay with UV detection has been optimized for determination of creatinine and xylene metabolites in human urine.

This assay in urine samples without pretreatment, provides a specific and reproducible alternative to currently available methods and, to our best knowledge, offers the level of sensitivity required to study the toxicokinetics of inhaled and percutaneous absorption of xylenes.

\section{Acknowledgments}

This research was supported by Centro de Investigação em Tecnologias da Saúde (Process n. ${ }^{\circ}$ AL18/2007) and Instituto Nacional de Medicina Legal, I.P. - Delegação Norte: Serviço de Toxicologia Forense.

\section{References}

ANTUNES MV, PATUZZI ALM, LINDEN R. Determinação simultânea de creatinina e indicadores biológicos de exposição ao tolueno, estireno e xilenos em urina por cromatografia líquida de alta eficiência. Química Nova, 31: 1865-1868, 2008.

BIENIEK G, PALYS E, WILCZOK T. TLC Separation of Hippuric, Mandelic, and Phenylglyoxylic Acids From Urine After Mixed Exposure to Toluene and Styrene. British Journal of Industrial Medicine 39: 187-190, 1982. 
BIENIEK G, WILCZOK T. Thin-layer chromatography of hippuric and m-methylhippuric acid in urine after mixed exposure to toluene and xylene. pp. 304-306, 1981.

ENGSTRÖM J, BJURSTRÖM R. Exposure to xylene and ethylbenzene. II. Concentration in subcutaneous adipose tissue. Scandinavian Journal of Work Environment \& Health, 4: 195-203, 1978.

OGATA M, HOBARA T. A new direct method for colorimetric determination of hippuric acid and methylhippuric acid as indices of toluene and m-xylene, and its application to workers using thinner. Industrial Health, 13: 75-78, 1979.

OGATA M, TAGUCHI T. Quantitation of urinary metabolites of toluene, xylene, styrene, ethylbenzene, benzene and phenol by automated high performance liquid chromatography. International Archives of Occupational and Environmental Health, 59: 263-272, 1987.

OGATA M, YAMAZAKI Y, SUGIHARA R, et al. Quantitation of urinary o-xylene metabolites of rats and human beings by high performance liquid chromatography. International Archives of Occupational and Environmental Health, 46: 127-139, 1980.

PERLINGOV I, DABROWSK L, STRÁNSKÝ V, et al. A rapid HPLC Method for the Determination of Carboxylic Acids in Human Urine Using a Monolithic Column. Analytical and Bioanalytical Chemistry, 378: 536-543, 2004.

RIIHIMAKI V, PFAFFLI P, SAVOLAINEN K, et al. Kinetics of M-Xylene in Man - General Features of Absorption, Distribution, Biotransformation and Excretion in Repetitive Inhalation Exposure. Scandinavian Journal of Work Environment \& Health, 5: 217-231, 1979.

ŠEDIVEC V, FLEK J. The absorption, metabolism, and excretion of xylenes in man. International Archives of Occupational and Environmental Health, 37: 205-217, 1976.

SZÜCS S, TÓTH L, LEGOZA J, et al. Simultaneous determination of styrene, toluene, and xylene metabolites in urine by gas chromatography/mass spectrometry. Archives of Toxicology, 76: 560-569, 2002.

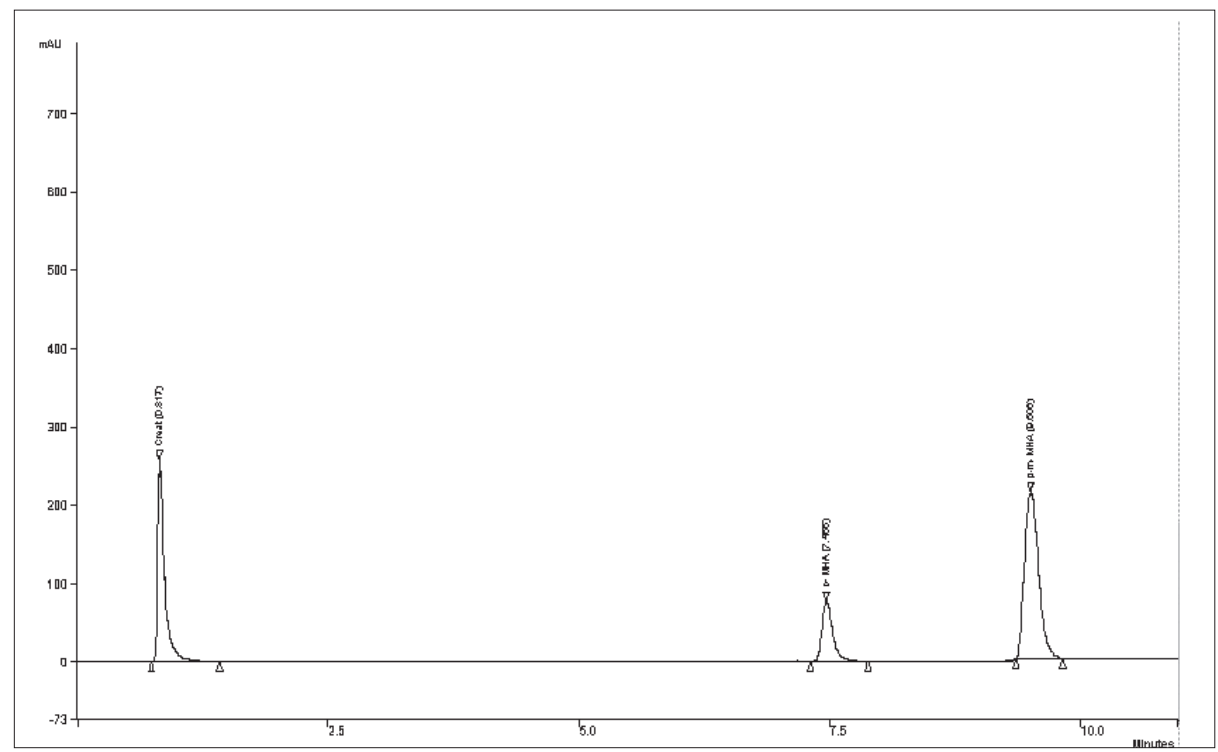

Figure 1 - Chromatogram $(\lambda=220 \mathrm{~nm})$ of a standard mixture of $\mathrm{g}+$ creatinine $(100 \mu \mathrm{g} / \mathrm{mL})$, o-MHA $(100 \mu \mathrm{g} / \mathrm{mL}), \mathrm{m}-, \mathrm{p}-$ MHAs $(100 \mu \mathrm{g} / \mathrm{mL})$. 


\begin{tabular}{ccc}
\hline Time $/$ min & Phosfate Buffer (\%) & Acetonitrile (\%) \\
\hline $\mathbf{0}$ & 95 & 5 \\
$\mathbf{7 . 5}$ & 80 & 20 \\
$\mathbf{1 0}$ & STOP & STOP \\
\hline
\end{tabular}

Table I - HPLC programmin showing the gradient of the mobile phase used to determine creatinine and metabolites of xylene

\begin{tabular}{lc}
\hline \multicolumn{1}{c}{ Analyte } & Concentrations $/\left(\boldsymbol{\mu g m L} \mathbf{L m}^{-1}\right)$ \\
\hline Creatinine & $10 ; 38 ; 66 ; 94 ; 100$ \\
o-MHA & $0.3 ; 13 ; 26 ; 39 ; 52$ \\
m-, p-MHAs & $0.3 ; 13 ; 26 ; 39 ; 52$ \\
\hline
\end{tabular}

Table II - Concentrations of analytes used in standard calibration curves

\begin{tabular}{lccccc}
\hline \multicolumn{1}{c}{ Analyte } & \multicolumn{2}{c}{ t-Student Test } & \multicolumn{3}{c}{ Linear Regression } \\
\hline & $\mathrm{t}_{\text {critical }}$ & $\mathrm{t}_{\text {obtained }}$ & $\mathrm{R}$ & $\mathrm{R}^{2}$ & $\mathrm{R}_{\text {máx }}^{2}$ \\
Creatinine & 2.3 & 1.85 & 0.9995 & 0.9991 & 0.9990 \\
0-MHA & 2.3 & 1.85 & 0.9989 & 0.9979 & 0.9976 \\
m-, p-MHAs & 2.7 & 2.13 & 0.9938 & 0.9876 & 0.9851 \\
\hline
\end{tabular}

Table III - Results of linearity tests for statiscal significance at 95 percent

\begin{tabular}{lcc}
\hline Analyte & LOD $/\left(\mu \mathrm{g} \mathrm{mL} \mathbf{~ L}^{-1}\right)$ & LOQ $/\left(\mu \mathrm{g} \mathrm{mL} \mathbf{~}^{-1}\right)$ \\
\hline Creatinine & 0.077 & 0.235 \\
o-MHA & 0.048 & 0.147 \\
m-, p-MHAs & 0.047 & 0.142 \\
\hline
\end{tabular}

Table IV - Limit of detection (LOD) and limit quantification (LOQ) of analytes

\begin{tabular}{lccc}
\hline \multirow{2}{*}{ Analyte } & $\mathbf{T}_{\text {ret }} / \mathbf{m i n}^{\mathbf{a}, \mathbf{b}}$ & \multicolumn{2}{c}{ Precision } \\
\cline { 3 - 4 } Creatinine & $0.82 \pm 0.01$ & $71663.5 \pm 6.36$ & $\mathrm{CV}(\%)$ \\
o-MHA & $7.43 \pm 0.01$ & $1250722 \pm 6074.05$ & $0.01-0.45$ \\
m-, p-MHAs & $8.98 \pm 0.02$ & $4354776 \pm 32993$ & $0.70-0.83$ \\
\hline
\end{tabular}

${ }^{\mathrm{a}}$ Retention times are mean $\pm \mathrm{SD}$.

${ }^{\mathrm{b}}$ Values obtined of standard calibrations curves $(\mathrm{n}=5)$.

${ }^{\mathrm{c}}$ Pick area are mean \pm SD.

Table V - Precision of the method 